DOI: https://doi.org/10.32839/2304-5809/2020-3-79-87

UDC 378.091.212-054.68-02626-044ю332(447)«20»

Smolikevych Nadiya

Ivan Franko National University of Lviv

Tsehelyk Halyna

Higher Educational Communal Institution of Lviv Regional Council

"Andrey Krupynsky Lviv Medical Academy"

Dunets Oksana

Ivan Franko National University of Lviv

\title{
FOREIGN STUDENTS' COMMON STUDYING PROBLEMS IN UNIVERSITIES IN UKRAINE
}

Summary. The article considers common problems that foreign students meet while studying in higher education in Ukraine. It outlines the university services that foreign students can be provided with. First of all, we are talking about orientation programs (brochures and leaflets that show examples of previous work with students on socio-cultural adaptation). Counseling offices can assist students in understanding the phenomenon of discrimination; conduct seminars and trainings covering various aspects of living and studying in Ukraine. Much attention was paid to orientation programs that provide information about the various stressors students face and how to overcome them in order to get adapted to new sociocultural and academic environment in order to study successfully.

Keywords: foreign students, adaptation, studying problems, orientation program, propedeutical training, universities in Ukraine.

Смолікевич H.P. Львівський національний університет імені Івана Франка

Цегелик Г.В.

ВНКЗ ЛОР «Львівська медична академія імені Андрея Крупинського»

Дунець O.P.

Львівський національний університет імені Івана Франка

\section{ЗАГАЛЬНІ ПРОБЛЕМИ НАВЧАННЯ ІНОЗЕМНИХ СТУДЕНТІВ В УНІВЕРСИТЕТАХ УКРАЇНИ}

Анотація. Стаття досліджуе загальні проблеми, з якими стикаються іноземні студенти під час навчання в університетах України. Вона описуе послуги університету, які можуть надаватися іноземним студентам. Перш за все, мова йде про орієнтаційні програми, які є доцільними на етапі рекрутингу (ознайомлення зі структурою, ресурсами та послугами університету, консультаційним офісом, брошури та листівки, які показують приклади попередньої роботи зі студентами над соціокультурною адаптаціею). Консультаційні офріси можуть допомогти студентам у розумінні явища дискримінації; проводити семінари та тренінги, що висвітлюють різні аспекти життя та навчання в Україні. Велика увага приділялася програмам орієнтації, які надають інформацію про різні стресові фактори, з якими стикаються студенти, та шляхи їх подолання з метою адаптуватися до нового соціокультурного та академічного середовища для успішного навчання. 3 метою академічної адаптації та подолання труднощів, з якими зіштовхуються іноземні студенти (низький рівень знань української мови та комунікативних умінь, відсутність або недостатність умінь налагодити стосунки з радниками та викладачами, психологічні труднощі звикання до системи вищої освіти та університетської освітньої діяльності (освітні програми, методи викладання, проведення тестувань тощо)), варто використовувати: курси пропедевтичної підготовки, вивчення української як іноземної, запровадження англомовних освітніх програм; удосконалення програм наставництва та програм радників іноземних студентів. Серед основних труднощів університетів у роботі з іноземними студентами стаття виокремлюе низький рівень фрінансового забезпечення, матеріально-технічної бази, не надто активна міжнародна діяльність університету та брак професійного розвитку викладачів для роботи у диверситивних полікультурних навчальних групах.

Ключові слова: іноземні студенти, адаптація, проблеми навчання, орієнтаційна програма, пропедевтична підготовка, університети України.

Problem statement. Having implemented a number of educational reforms Ukraine has not reached the level of European universities yet as its universities do not meet the requirements of today due to many reasons. The main of them is the low level of material and technical base of universities and training of specialists. A positive characteristic of reforming Ukrainian education is the change from an authoritarian teaching approach to the humanistic one.

It is well-known fact that Ukrainian higher educational institutions should be more open. Also, it is necessary to improve the learning of foreign languages by improving language teaching, creating a language-friendly environment [7, p. 19]; extending the system of teaching different disciplines in a foreign language in order to increase the number of foreign students who would like to get higher education degrees in Ukraine, which will increase the financial income of the institutions and, accordingly, gives the universities more opportunities to improve their services, financial status, and it also enhance research activity and international cooperation in educational sphere. 
According to Vasyl Kremen, the new tasks in higher education are: to prepare a person for life in an innovative, globalized democratic society, capable of being an active member of the knowledge society, for whom knowledge becomes the basis, the methodology of action, and determines the essence of the individual; to form in man a modern system of values, built on the humanistic principles of society. According to the author, this can be achieved through student-centered learning and upbringing process $[6$, p. 4].

The purpose of our research is to find out the main problems of the academic study of foreign students in Ukraine, comparing it with the state of solving such problems in Europe and the USA.

It should be noted that a global educational environment is not possible without the internationalization of education, the development of common standards of education and training, which enhance the possibility of choice or change of universities for young people, including from abroad, and the exchange of students or teachers. It provides interpersonal, intercultural and inter-ethnic exchange of experience.

We state that under the condition of the internationalization of education, it is important for Ukraine to follow educational globalization trends, which are based on partnership, openness, dialogue, goodwill, respect, lifelong learning, etc. as each state determines its educational policy and strategic tasks.

Experience in the international environment is important in the global labor market too since lots of employers are looking for experienced and multicultural professionals.

So, the main goal of the contemporary university in Ukraine is to organize a favorable educational environment on the values of a democratic civil society and to create a coherent system of pedagogical activity, based on democratic methodologies of teaching and civic discourse in educational diversification classes. In such an environment, it is necessary that learning should be interesting and easy with respect for others. Although, it is not easy to educate such a teaching staff, since it requires, first and foremost, a critical attitude towards oneself, a reassessment of some personal values $[4, \mathrm{p}$. XXIV].

Since 2005, when Ukraine supported the globalization process of "borderless learning" with the transition to a unified higher education system, the Bologna Declaration on the creation of a single European educational space has been signed. Obviously, Ukraine is trying to gain a decent place among other universities in Europe.

Junor \& Usher (2008) define student mobility as an academic one that is implemented within an educational program for a term of one semester before completing a certain educational degree [3].

Statistics show an increase in foreign students in Ukrainian universities every year. In 2018 , there were a total of 66,330 students from 147 countries. The largest number of students comes from India and Azerbaijan: 16.4\% and $11.3 \%$ respectively. The top ten countries are Morocco, Turkmenistan, Nigeria, Georgia, Turkey, Egypt, Uzbekistan and Jordan. The top universities according to the number of foreign students are: Kharkiv National Medical
University and V. Karazin Kharkiv National University, Vinnytsa National Pyrogov Medical University, Zaporizhzhia State Medical University, O.O. Bogomolets National Medical University, Odesa National Medical University, I. Horbachevsky Ternopil National University. 7 out of 10 top universities in this ranking are specialized medical institutions. Accordingly, Kharkiv, Kyiv, Odesa, Dnipropetrovsk, and Zaporizhzhia regions are leaders in the number of foreign students [12].

International students have traditionally chosen medical specialization (up to 50\%) and less than $10 \%$ economic, engineering and legal specialties [12].

Also, the number of Ukrainian higher education institutions with foreign students is increasing gradually: in 2015-2016 there were 185 establishments, and in 2017 - 239 [12].

Having studied the publication on the problem we can single out the core reasons for choosing Ukrainian universities be foreigners, which are: the appropriate quality of higher education and the favorable cost of university studying, low cost of living, enjoyment of the same rights and freedoms as Ukrainian citizens, etc.

Previously unsolved parts of the general problem. Scientific and pedagogical sources on this topic have shown that a comprehensive study of common problems of foreigners-students of higher education institutions in Ukraine has not yet been completed and single out.

The research objective. Our aim is also to describe thoroughly them in the context of adaptation process.

The main body of the research. However, after arriving in Ukraine, foreign students are faced with a number of problems that need assistance: ordering documentation to preserve immigration status and residence, transportation, finances, food, clothing, etc.; learning about academic culture, that means knowing how to interact with teachers and other students, as well as adapt to different learning styles; the challenges of cultural adaptation in a multicultural environment, meeting new friends and adapting to a new social support system.

The first problems occur at the beginning of the adaptation process and connected with staying in an unfamiliar environment. In addition, circumstances such as group heterogeneity, lack of Ukrainian language proficiency knowledge, and discrimination experience may be additional barriers to cause some students' adaptation difficulties and problems in their successful studying. The result of the adaptation process affects not only the learning success but also the students' psychological well-being and health.

Therefore, university staff should pay more attention to foreigners through organizing various joint events, seminars, discussions at "the round table" and carrying out other kinds of activities; and create favorable organizational and pedagogical conditions in order to ensure successful adaptation and meet their academic and professional needs.

We consider it is necessary to outline the university services that foreign students can be provided with. First of all, we are talking about orientation programs (brochures and leaflets that show examples of previous work with students on 
socio-cultural adaptation). Counseling offices can assist students in understanding the phenomenon of discrimination; conduct seminars and trainings covering various aspects of living and studying in Ukraine.

In the initial phase of adapting to the new environment, it is worthwhile to introduce university orientation programs that provide information about the various stressors students face and how to overcome them. In addition, it is advisable to get acquainted foreigners with Ukrainian students and communities, as all these contacts will help to reduce stress during the initial adaptation process.

International students face the problem of making new friends, overcoming the loss or lack of socio-cultural support, and feel difficulties in creating a new system of such support. The loss or lack of sociocultural support causes a decline in academic achievements and adversely affects the psychological state of students, which is accompanied by stress, inattention, irritability, and depression. Upon arrival in Ukraine, individuals perceptions of the country and its culture are different from those they experienced in their home country, which is mostly influenced by the similarity or difference of cultures, social order, and, of course, psych type (extraversion / introversion) of the persons, their communication skills (command of Ukrainian) and a positive approach to forming relationships with Ukrainians [1]. Foreigners, who are getting well with Ukrainian students, are gaining a positive experience. Therefore, positive communication with students and faculty staff helps reduce stress and adapt to the social and cultural environment. Engaging in extracurricular activities (hobbies, students' clubs, community work, volunteering, etc.) is important since it helps in international students adaptation to socio-cultural, psychological and academic unfamiliar environment and, as a result, reduces stress, make easier to develop a support network and obtain social competence.

Also, it is worth considering the role of orientation programs in more detail, as their mission is to provide international students with the necessary information and resources to successfully adapt and guide them in choosing the best learning strategies. Orientation programs for international students in different universities may vary, which depends objectively on factors such as the size of the institution, the number of international students studying there, staff support, budget, campus culture, etc.

Having studied and analyzed European and US experience we have come to the conclusion that orientation programs should include such items:

- foreign entrants' preparation of for travel (encouragement to attend a free session on preparation before arrival in the country, higher education institution);

- interpretation of immigration provisions (issues of maintaining immigration status, necessary documents, other information);

- students' readiness to study abroad (encouragement to attend a free session on preparation for arrival in the country, higher education institution);

- explanation and interpretation of immigration provisions (issues of maintaining immigration status, necessary documents, other information);
- Guidelines after arrival in Ukraine (detailed information on how to behave upon arrival at the airport (e.g. advice on passing customs control, transfer from the airport to the university, if it is needed, rules of registration at university, accommodation options: campus, renting accommodation near the institution), etc.;

- separate specialized program: orientation guidance exclusively for foreign students, before the general orientation program for all new students of university (it helps students determine the subjects (what they want to study and what experience they want to get)) and also creates opportunities for acquaintance with each other in a relaxed atmosphere;

- foreign student support services (getting to know about the list of departments with certain types of services, e.g. medical, psychological services, security (police department), recreational programs, student life, academic counseling and registration, community activities, etc., information on free and paid services);

- socio-cultural adaptation: acquainting students with the problems of the adaptation period (homesickness, anxiety, depression and stress), their consequences and the importance of coping with them with the help of friends or student self-government, counseling centers and other services; providing them with the literature that will facilitate their cultural adaptation and reduce its negative manifestations;

- adaptation to the academic environment: familiarization with the country's education system and the system of education in university, consideration of how to succeed in learning (behavior in class and expectations); discussions on: counseling services, academic virtue, group work, student-student, student-students or teacher-students relationships that are going to help structure learning expectations and goals, reviewing the literature on adaptation to the academic environment [8]

The process of foreign students' orientation preparation may require the interaction of responsible university staff or the partnership of several departments / services operating within the university. Orientation programs may cover the following tasks before and during the study of foreign students:

- performing priority tasks, such as photocopying documents (visa and passport), as well as obtaining or updating student contact information, including current address, email address, and a telephone number;

- introductory sessions on immigration regulations, visa requirements while traveling from and to the country, etc.;

- organizing a campus tour to get acquainted with the infrastructure of the campus, which contains the library, bookstore, university clinic, international student department, canteen, common dormitories and offices that ensure successful adaptation and student learning;

- getting cooperation with the faculty for the purpose of planning seminars on class behaviors, academic expectations and integration, plagiarism, student behaviors, university rules;

- extending cooperation with medical and psychological services in order to solve adaptation problems; 
- discussions on the harmfulness of alcohol, tobacco, drugs, the importance of new dating, the inadmissibility of pressure from student mentors or intimidation;

- cooperation with various services (security department, fire department, police, campus administration, etc.) of the university on safety and emergency alert systems;

- collaboration with student self-government, volunteer organizations;

- participation in student circles, clubs, sports sections for the purpose of socialization;

- providing information for students about the possibility of finding accommodation outside the campus, renting accommodation;

- organization of seminars or offering online information on how to get a phone number, open a bank account or manage finances [8].

Having analyzed the statistics of the number of foreigners in higher educational establishments of Ukraine, we have concluded that Ukraine and its culture are attractive to representatives of other countries. Significantly, a lot of foreign students receive education in Ukraine that is affordable and close to European standards. Ukraine is the most accessible country in Europe, attracting foreigners who become students, mostly to become medical, technical, legal and diplomatic specialties.

The experience of universities in advanced countries shows that knowledge of the language of instruction is an important factor in predicting students' academic achievement.

In Ukraine, a mandatory demand for foreigners' entry into universities is proficiency in the Ukrainian language at B1 level. And, the organization of foreign students adaptation process to study in Ukrainian institutions, which is discussed in the interstate agreements, provides primarily for language training, i.e. the study of Ukrainian as a foreign language - a discipline, in accordance with the Law of Ukraine "On Education" (2017, pp. 67, 68) [11] and with the aim of improving the quality of training of specialists for foreign countries" [9].

Propaedeutical training, which lasts a year (from 720 to 838 hours depending on the chosen specialty), provides mastering of Ukrainian language of levels $\mathrm{A} 1, \mathrm{~A} 2, \mathrm{~B} 1$ and adjusts foreigners to stay in a new linguistic and cultural environment [10].

But, in our opinion, more foreigners would come to study if each institution provided them with the choice to study in English or Ukrainian. Because it is easier for them to learn English, or there are situations that it is also their language of communication at home, and modern qualitative scientific sources are much more in English. This will make it much easier for them to take up the learning tasks and the also they will have the opportunity to continue their study not only in Ukraine, but also abroad. We agree that they need to know the Ukrainian language mostly at the household level.

As for the educational process at the preparatory department, we should stress that it is the most important component of the propedeutic stage of foreign students' adaptation. Its effectiveness helps foreign higher education applicants study sucessfully, get adopted to living and academic ruled in Ukraine, as well as improve their general knowledge necessary for university studying.

Propedeutical training of foreigners is realized in three directions: communicative (communicative competence), general scientific (professional competence), adaptation (acculturation to the realities of life in a foreign language environment).

We agree with Kovalenko that pre-university preparation of foreigners covers the following components: studying of the Ukrainian language to a level sufficient for study in the first year of university; adjusting the level of knowledge in the sphere of the chosen specialty; students' adaptation to the new socio-cultural environment; acquaintance with the culture and traditions of Ukraine [5, p. 93].

According to Chestiakova, academic adaptation is directly proportional to the command of the Ukrainian language, since the description of the professional disciplines introduced at the initial stage of training in the propaedeutic course, the tasks of control works, exam tickets), the names of the disciplines (in the schedule and credit book) are in Ukrainian [2].

It should be added that foreign students' aptation involves getting used to the peculiarities of the educational organization: the schedule of classes, teaching methods, behavior in class, structural and content organization of the lesson, style and personality of the teacher, etc. [5, p. 99].

Although Kovalenko, Krevs, and Tsisar [5] schematically identify the place of "adaptation of foreign students in the context of the studying organization in propaedeutical training, which is not related to the study of Ukrainian as a foreign language" (p. 94), it is obvious that the adaptation of foreigners, occurs only within the framework of the course of the Ukrainian language as a foreign language, which is not the main task of the discipline (Tabl. 1).

Research conclusions. Having studied this topic thoroughly, we can state that in the process of academic adaptation foreign students face such core difficulties, as: a low level of knowledge of the Ukrainian language and communication skills; inability to establish relationships with advisers and teachers or to get on well with group mates or other students; and difficulties in getting used to the educational system of Ukraine and university edu-

Organization of training at the preparatory faculty of Ukrainian universities [5]

\begin{tabular}{|c|c|c|}
\hline \multicolumn{3}{|c|}{ Organization of training at the preparatory faculty of Ukrainian universities } \\
\hline $\begin{array}{c}\text { Academic adaptation, educational } \\
\text { process }\end{array}$ & $\begin{array}{c}\text { Foreign stuidents' } \\
\text { sdaptation to new } \\
\text { sociociltural environment }\end{array}$ & $\begin{array}{c}\text { Organization } \\
\text { of the teacher' work }\end{array}$ \\
\hline $\begin{array}{c}\text { The Ukrainian } \\
\text { language studying }\end{array}$ & $\begin{array}{c}\text { Studying } \\
\text { speciality subjects }\end{array}$ & \\
\hline
\end{tabular}


cational activities (educational programs, teaching methods such as discussions, quizzes, or encouragement to ask questions on the subject of study, and testing).

Expanding international relations, facilitating communication, learning about the cultural traditions and characteristics of the foreign country of study greatly accelerate and facilitate the adaptation process.

Adaptation problems for foreign students in Ukraine are similar to those in advanced countries, although it is more difficult for Ukrainian higher education institutions to address them due to lack of funding and inadequate level of resources.

\section{References:}

1. About teaching foreign language students at Ukrainian universities. Theory and Practice of Teaching Ukrainian as a Foreign Language, 7, 34-41.

2. Chystiakova, A. (2012). Pro navchannia inozemnykh uchniv movy u VNZ Ukrainy.

3. Junor, S., \& Usher, A. (2008). Student mobility and credit transfer: a national and global survey. Virginia: Educational Global Institute.

4. Koshmanova, T., Brice, L., Holm, H., Nations Jonson L., Ravchyna, T., \& Rao, Sh. (2005). Pedahohika dlia hromadianskoho suspilstva [Pedagogy for Civil Society]. (ed. T.S. Koshmanova). Lviv: Publishing Center of Ivan Franko National University of Lviv.

5. Kovalenko, V., Krevs, V.\& Tsisar, N. (2016). Orhanizatsia douniversytetskoho navchannia inozemnykh hromadian. [Organization of pre-university training of foreign citizens]. Theory and Practice of Teaching Ukrainian as a Foreign Language, 1, 93-102.

6. Kremin, Vasyl (2006). Osvita I systema vykhovannia povynni pereoriyentuvatysia na formuvannia u liudei innovatsiynoho pypu myslennia [Education and upbringing system should be oriented towards the formation of innovative type of thinking in people]. Foreign languages in educational institutions, $2,4$.

7. Shyian, R. (2006). Yevropeyskyi vymir movnoi osvity [European Dimension of Language Education]. Foreign Languages in Schools. 2, 19.

8. Smolikevych, N.R. (2018). Orhanizatsiino-pedahohichne zabezpechennia adaptatsii inozemnykh studentiv $\mathrm{v}$ universytetakh SSHA [Organizational and pedagogical provision of foreign students' adaptation in US universities]. Qualificative research paper as a manuscript. The author's dissertation thesis for obtaining the scientific degree of candidate of pedagogical sciences: 13.00.01. Ivan Franko National University of Lviv. Lviv, 236.

9. Palinskaya, O. (2011). Korektsia pomylok studentiv u kursi ukrainskoi movy yak inozemnoi. [Correction of students' mistakes in the course of Ukrainian as a foreign language]. Theory and Practice of Teaching Ukrainian as a Foreign Language, 6, 204-210.

10. Ushakova, N., \& Trostynska, O. (2014). Vyvchennia ukrainskoi movy studentamy-inozemtsiamy: kontseptualni zasady. [Studying the Ukrainian language by foreign students: conceptual backgrounds]. Theory and Practice of Teaching Ukrainian as a Foreign Language, 9, 12-21.

11. Education ua (2017). Zakon Ukrainy pro osvitu vid 05.09.2017 [Law of Ukraine "On Education" of 05.09.2017]. Available at: http://osvita.ua/legislation/law/2231/ (accessed 03 October 2018).

12. Laskavo prosymo: yak inozemtsi yidut' na navchannia do Ukrainy [Welcome: how foreigners go to study in Ukraine]. Available at: https://studway.com.ua/inozemtsi-v-ukraini/ (accessed 21 February 2020). 